\title{
情報理論を用いた生態ネットワークの 集約化法
}

$\begin{array}{lllll}\text { 正員 平 田 廣 則 (千篍大) } \\ \text { 正員 須 貝 康 雄 } & \text { (千葉大) }\end{array}$

\section{1.はじめに}

近年，生態システムの分野に打いて集約化の重要性 が指摘されている(1)(2)。集約化 (Aggregation) は, 経済 ${ }^{(3)}$ や工学(4)(5)の分野に打いて端を発し，種々の方 面で研究が進められた。集約化には二つのタイプがあ る：(a)対象とするシステムをブラックボックスとみ なし，ある入力に対する集約化モデルの出力ともとの システムの出力（観测）の近さを評価関数とする。

(b)対象上するシステム內部の主要な構造が極力保存 されるように集約化モデルの構造上元のシステムの構 造の近さを評洒関数とする。

本文では，生態システムの一つのモデルとして，種 族を要素, 種族間のつながり（エネルギーや物質の流 机）を有问枝とする生態ネットワークを考えることに より，前出の集約化の (b)の立場での新しい集約化手 法を提案するととむに，その手法を用いることによ り，生態ネットワークの要麦をグループ化し，生翣ネ ットワークの主要なマクロな構造（主として，䀝層構 造)をシステムの中に見い出すととが可能なことを示 ఫ。

具体的に时，生態六ットワークのエネルギーや物質 の流れによる移動に対して情報理論における通信路と のアナロジーを用い，生態ネットワークの構造の持つ 情埌を定義する。集約化比よるその情報量の減少量を 評価関数とすることにより，その評洒関数の值が最小 となる場合を最適な集約化とする。

本文での集約化の考えを実際の生態システムからの いくつかのデータに適用し，階䁲棈造などのマクロな 㯲造を見い出す。

\section{2. 生龍ネットワーク}

図10ような生態ネットワークを考える。本ネット

Aggregation Method for Ecological Networks Using Information Theory. By Hironori Hirata, Member, \& Yasuo Sugai. Mernber (Department of Electronics, Faculty of Engineering, Chiba University)

平田庭则: 正員, 千篗大学工学部電子工学科

須貝麻雄: 正宣, 干葉大学工学部電子工学科
ワークは, エネルギーフローによって特徴付けられて いるが，炭素フロ一，窒素フロ一，物質フローなどで 表されていてもよい。 $k$ 番目の要素は図 20 よう俵 される。

$T_{k j}: k$ 番目の要素加 $j$ 番目の要素へのフロー

$D_{k}: k$ 番目の要素加外界への散逸フロー

$E_{k}: k$ 番目の要素加ら他のネットワークへのフ 口-

$I_{k}: k$ 番目の要素への外界加らの入力フロー ここで， $T_{k j}, D_{k}, E_{k}, I_{k}$ は，亩べて非角である。

$k$ 番目の要素加流れ出るフロ一の総和を, 次のよ うに $T_{k}$ と置く。

$$
T_{k}=\sum_{j=1}^{n} T_{k j}+D_{k}+E_{k}
$$

次のようなベクトル，行列表示を用いる。

$$
\begin{aligned}
& T=\left(T_{k}\right)^{t} k=1, \ldots, n=\left(T_{1}, \ldots, T_{n}\right)^{t} \\
& D=\left(D_{k}\right)^{t} k=1, \cdots, n \\
& E=\left(E_{k}\right)^{t} k=1, \cdots, n \\
& I=\left(I_{k}\right)_{k=1, \cdots, n} \\
& T^{\circ}=\left\{T_{k j}\right\}_{k, j=1, \cdots, n}
\end{aligned}
$$

ここで，(t) はべクトルの転置を表す。(1)式は(2) 式より次のように表せる。

$$
T=T^{\circ} 1+D+E \text {. }
$$

ここで, $1=(1, \cdots, 1)^{t}$ とする。定常状態では，

$$
T_{k}=\sum_{l=1}^{n} T_{t k}+I_{k}
$$

なので,

$$
T=T^{\circ} 1+D+E=T^{\circ} 1+I
$$

\section{3. 通信路と相互情報量}

図3のような通信路を考える。入力アルファベット $A$ は, 文字 $a_{k}(k=1, \cdots, n)$ よりなり, その生起確率 を $P\left(a_{k}\right)$ と表す。出力アルファベット $B$ は, 文字 $b_{j}$ $(j=1, \cdots, r)$ 上りなり, その生起確率を $P\left(b_{j}\right)$ と表す。 無記憶通信路は，入力加 $a_{k}$ のときに出力 $b_{j}$ 加生起す る条件付き確率 $P\left(b_{j} / a_{k}\right)(j=1, \cdots, r, k=1, \cdots, n)$ k より特徽付りられる。乙れを遷移確率と呼び, $M=\{P$ 


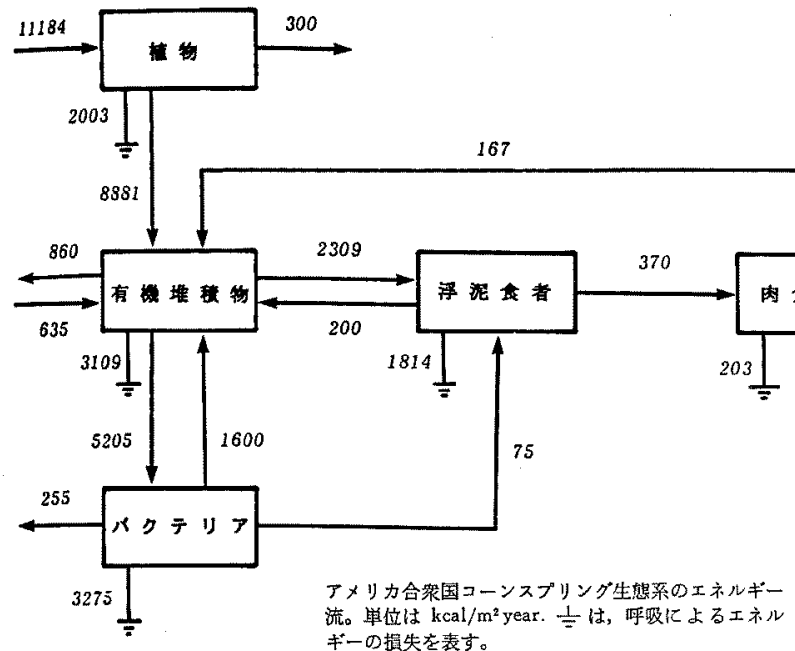

困 1 生態ネットワークの例

Fig. 1. An example of ecological network.

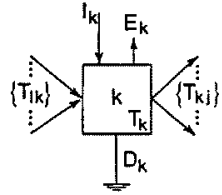

困 $2 k$ 番目の要素

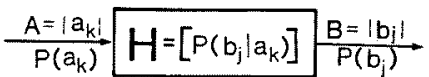

図 3 通信路

Fig. 3. Channel.

$\left.\left(b_{j} / a_{k}\right)\right\}_{k=1}, \cdots, n, j=1, \cdots, r$ を通信路行列と呼ぶ。

ここで, $\sum_{j=1}^{r} P\left(b_{j} / a_{k}\right)=1$

の関係が成り立つ。入力生起確率と出力生起確率の関 係は摡移確率を通して次の関係がある。

$$
P\left(b_{j}\right)=\sum_{k=1}^{n} P\left(b_{j} / a_{k}\right) P\left(a_{k}\right)
$$

$A$ のエントロピーと $B$ が与えられたときの $A$ の 条件付きエントロピーは，次のように定義される。

$$
\begin{aligned}
& H(A)=-\sum_{k=1}^{n} P\left(a_{k}\right) \log P\left(a_{k}\right) \\
& H(A / B)=-\sum_{j=1}^{r} P\left(b_{j}\right) \sum_{k=1}^{n} P\left(a_{k} / b_{j}\right) \\
& \cdot \log P\left(a_{k} / b_{j}\right)
\end{aligned}
$$

$H(A)$ は， $(B$ を知吕前の） $A$ の不確定性, $H(A / B)$ は， $B$ を知った後の $A$ の不確定性を示す。

入力 $A$ 亡出力 $B$ の間, すなわ方, 通信路の相互情 報量は

$$
\begin{aligned}
H(A ; B)= & H(A)-H(A / B) \quad \ldots \ldots . . \\
= & H(B)-H(B / A) \quad \ldots \ldots . . \\
= & \sum_{k=1}^{n} \sum_{j=1}^{r} P\left(b_{j} / a_{k}\right) P\left(a_{k}\right) \\
& \cdot \log \left[P\left(b_{j} / a_{k}\right) / P\left(b_{j}\right)\right] \ldots .
\end{aligned}
$$

と表せる。

$$
\begin{aligned}
P\left(a_{k}, b_{j}\right) & =P\left(b_{j} / a_{k}\right) P\left(a_{k}\right) \\
& =P\left(a_{k} / b_{j}\right) P\left(b_{j}\right)
\end{aligned}
$$

を用いて，次の上うに变形できる。

電学綸 C, 107 巻 8 号, 昭 62

$$
\begin{aligned}
M(A ; B) & =\sum_{k=1}^{n} \sum_{j=1}^{r} P\left(a_{k}, b_{j}\right) \\
\cdot & \log \left[P\left(a_{k}, b_{j}\right) / P\left(a_{k}\right) P\left(b_{j}\right)\right] \ldots
\end{aligned}
$$

$M(A ; B)$ は, 通信路の出力の観測によって得られる 入力に関する情報量を表す。

\section{4. 生態ネットワークの情報量}

〈4.1〉理諭的形式 図40よ5なフロー分布に 着目したモデルを考える。入力を要素 0 ，他のネット ワークへの出力を要素 $n+1$, 外界へ失われる出力を 要素 $n+2$ として, $n$ 個の種族の要素に加えるととに 上り, $n+3$ 個の入力端子亡 $n+3$ 個の出力端子をあつ 生態通信路を考える。要素 $0, n+1, n+2$ を一つ要

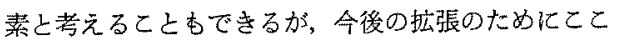
では前述のモデルを用いる。

フローがある要素から他の要素へ流れるために必要 な時間を $\theta$ とする。事象 $a_{k}$ を，ある媒体（炭素，堂 荎, 物質，エネルギーなど）加時刻 $t$ 、において要素 $k$ 老通過するとと，事象 $b_{j}$ 字，その媒体が時刻 $t_{1}+\theta$ において要㨞 $j$ を通過するとととする。

$P\left(a_{k}\right)$ : 時刻 $t_{1}$ に抽いて媒体力㴗素 $k$ を通過する確 率。

$P\left(b_{f}\right)$ : 時刻 $t_{1}+\theta$ において媒体が要素 $j$ 通過す 方磼率。

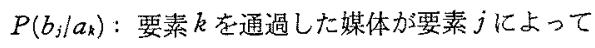
取り入れられる確率。

（14）式より，本生態通信路の相互情報量, すなわち 


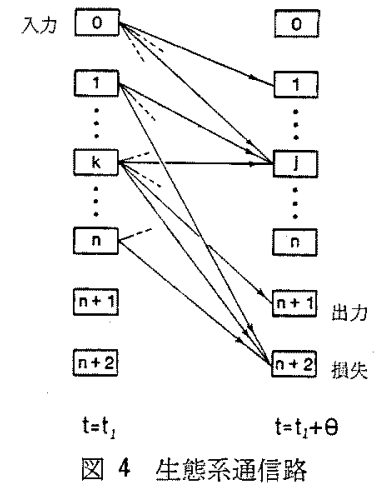

Fig. 4. Ecological channel.

生態ホットワーク $N$ の構造の含む情報は，次のよう に表せる。

$$
\begin{aligned}
M(N)= & M(A ; B)=\sum_{k=0}^{n+2} \sum_{j=0}^{n+2} P\left(a_{k}, b_{j}\right) \\
& \cdot \log \left[P\left(a_{k}, b_{j}\right) / P\left(a_{k}\right) P\left(b_{j}\right)\right] \ldots \text { (15) }
\end{aligned}
$$

〈4-2〉応用形式 次に图10ような実際口生態 ネットワークへの応用を可能とするために，以下に示 すフロー分布の比率を近似的に確率よみなし，理諭的 形式(15)式を変形する。

$Q_{k}$ : 時刻 $t_{1}$ において, 要素 $k$ を通過するフロー の全フロ一量に対する比率。 $Q_{k} \geqq 0(k=0$, $\cdots, n), Q_{n+1}=Q_{n+2}=0$ 。

$P_{j}$ : 時刻 $t_{1}+\theta$ に打いて, 要菜 $j$ を通過する全フ 口一量に対する比率。 $P_{j} \geqq 0(j=0, \cdots, n)$, $P_{n+1}=P_{n+2}=0_{0}$

$f_{k j}$ : 時刻 $t_{1}$ に术いて要素 $k$ を通過したフローの うち，時刻 $t_{1}+\theta$ において要琹 $j$ 几流入する 比率。 $f_{k j} \geqq 0$ 。

$r_{k}$ : 時刻 $t_{1}$ に扔いて要素 $k$ を通過したフローの う方外界八失和れるフロ一の比率。 $r_{k} \geqq 0$ 。

$e_{k}$ : 時刻 $t_{1}$ に扔いて要素 $k$ を通過したフローの うち他のネットワークヘのフローの比率。 $e_{k} \geqq 0_{0}$

これらの変数には，次の関係式か成り立つ。

$$
\begin{array}{r}
P_{j}=\sum_{k=0}^{n} f_{k j} Q_{k} \quad(j=1, \ldots, n) \\
P_{n+1}=\sum_{k=1}^{n} e_{k} Q_{k} \ldots \ldots \ldots \ldots \ldots \ldots . \\
P_{n+2}=\sum_{k=1}^{n} r_{k} Q_{k} \quad \ldots \ldots \ldots \ldots \ldots \ldots \\
\text { 乙で, } \sum_{j=1}^{n} f_{k j}+r_{k}+e_{k}=1 \\
\sum_{j=1}^{n} f_{0 j}=1 \ldots \ldots \ldots \ldots \ldots \ldots \ldots \ldots
\end{array}
$$

$$
\begin{aligned}
& \text { 生態ネットワーク } N \text { において， } \\
& P\left(a_{k}\right)=Q_{k} \\
& P\left(b_{j}\right)=P_{j} \\
& P\left(b_{j} / a_{k}\right)=f_{k j}
\end{aligned}
$$

と㯰くことにより，生態通信路の情報量を求める。具 体的には，図 1 のうな生態亦ットワークのデータを 用いて, 次のように $Q_{k}, f_{k i}, r_{k}, e_{k}$ を表すととがで きる。

$$
\left.\begin{array}{l}
Q_{k}=T_{k} / T \quad(k=1, \cdots, n) \\
Q_{0}=I / T \\
f_{k j}=T_{k j} / T_{k} \quad(k, j=1, \cdots, n) \\
f_{0 j}=I_{j} / I \quad(j=1, \cdots, n) \\
f_{k 0}=0 \quad(k=0, \cdots, n) \\
r_{k}=D_{k} / T_{k} \ldots \ldots(26), \quad e_{k}=E_{k} / T_{k} .
\end{array}\right\} .
$$

ここで, $T^{*}=T+I$

$$
\begin{aligned}
& T^{*}=\sum_{k=1}^{n} T_{k}{ }^{*} \\
& I=\sum_{k=1}^{n} I_{k} \ldots \ldots
\end{aligned}
$$

以下においては，表現の簡単化をはかるたるに， $D_{k}=T_{k n+1}, \quad E_{k}=T_{k n+2}, \quad I_{k}=T_{0 k}$ と書くことがある。

性質 1. 生態ネットワーク $N$ の搆造が含む情報 量 $M(N)$ は, 次のよう债せる。

$$
\begin{aligned}
M(N)= & (1 / T) \sum_{k=0}^{n} \sum_{j=1}^{n+2} T_{k j} \\
& \cdot \log \left(T T_{k j} / T_{k} T_{j}\right)
\end{aligned}
$$

性質 1 は，(15)式に (21)〜 (30) 式を用いることによ り求まる。

\section{5. 集約化によるマクロ構造の同定}

\section{$\langle 5 \cdot 1\rangle$ 集約化}

定義 1 . 要素の集合 $N$ と $\bar{N}$,

$$
\begin{aligned}
& N=\left\{\alpha_{k}\right\}_{k=1}, \ldots, \\
& \bar{N}=\left\{\beta_{i}\right\}_{i=1}, \ldots, m
\end{aligned}
$$

ここで, $m \leqq n$ とし, 準同形写像 $\Phi$,

$$
\Phi: N \rightarrow \bar{N}
$$

を定義する。 $N$ を元のネットワーク， $\bar{N}$ を集約化ネ ットワーク， $ゆ$ を集約写像と㭔ふ。

集約写像の一表現として，次の上うな行列表現を用 いる。

定義 2. 集約行列 $S$ を次のように定義する。

$$
\begin{aligned}
& S=\left[s_{i k}\right]_{i=1, \cdots, m, k=1, \ldots, n}
\end{aligned}
$$

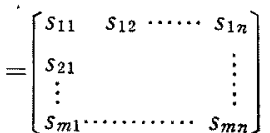




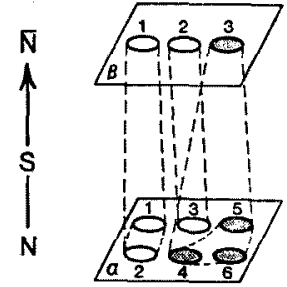

図 5 離散的集約化

Fig. 5. Discrete aggregation.

こてで,

$$
0 \leqq s_{i k} \leqq 1, \quad \sum_{i=1}^{m} s_{i k}=1
$$

$s_{i k}$ が0か1のとき, 離散集約化(5) という。その他 の場合，重み付き笨約化之呼ふ。。離散的集約化は，重 み付き集約化の特別の場合である。

例 1. 離散的集約化の例を示す（図 5)。

$$
\begin{aligned}
& N=\left\{\alpha_{1}, \alpha_{2}, \alpha_{3}, \alpha_{i}, \alpha_{5}, \alpha_{6}\right\} \\
& \bar{N}=\left\{\beta_{1}, \beta_{2}, \beta_{3}\right\} \ldots \ldots \ldots \ldots \ldots \ldots
\end{aligned}
$$

$$
S=\left[\begin{array}{llllll}
1 & 1 & 0 & 0 & 0 & 0 \\
0 & 0 & 1 & 0 & 0 & 0 \\
0 & 0 & 0 & 1 & 1 & 1
\end{array}\right)
$$

のとき，

$$
\left.\begin{array}{l}
\beta_{1}=\alpha_{1}+\alpha_{2}, \quad \beta_{2}=\alpha_{3} \\
\beta_{3}=\alpha_{4}+\alpha_{5}+\alpha_{6}
\end{array}\right\}
$$

集約化ネットワーク $\bar{N}$ について (2) 式上同様に

$$
\left.\begin{array}{l}
\bar{T}=\left(\bar{T}_{k}\right)_{k=1, \cdots, m,} \quad \bar{D}=\left(\bar{D}_{k}\right)_{k=1}^{t}, \ldots, m \\
\bar{E}=\left(\bar{E}_{k}\right)_{k=1}{ }_{k=1}, \cdots, m, \quad \bar{I}=\left(\bar{I}_{k}\right)_{k=1}, \cdots, m \\
\bar{T}^{\circ}=\left\{\bar{T}_{k j}\right\}_{k, j=1, \ldots, m}
\end{array}\right\}
$$

ここで, 記号(ー)は集約化後を示す。(3)式と同じよ うに

$$
\bar{T}=\bar{T}^{\circ} 1+\bar{D}+\bar{E} .
$$

加成り立つ。

性貿 2. 集約化前のネットワーク $N$ の変数と, 集約化後のネットワーク $\bar{N}$ の变数の間に次の関係が 成り立つ。

$$
\left.\begin{array}{ll}
\bar{T}=S T & \bar{D}=S D \\
\bar{E}=S E & \bar{I}=S I \\
\bar{T}^{\circ}=S T^{\circ} S^{t} &
\end{array}\right\}
$$

性質 2 加ら明らかなように集約化㣪のネットワーク は笨約行列 $S$ の関数亡なり， $\bar{N}(S)$ と表される。

集約化の前後において情報量は，次のように变化す 引。

性罂 3. 集約化の過程に侾いて; 次の関係が成り 立つ。

$$
M(N) \geqq M(\bar{N})
$$

付録に証明を示す。

性質 3 は，集約化することにより情報量は增加しな いととを意味する。すなわち，通常は失われることを 示している。この情赦量の損失を評価関数 $J$ とする。

$$
J=M(N)-M[\bar{N}(S)]
$$

$J$ を最小にするように最適な $S *$ を求める。

本諭文に拈いては，離散的集約化，すなわち，Sの 要素が 0 上1のみ加らなる場合について取り报う。

$\langle 5 \cdot 2\rangle$ 集約化の損失がない場合 最初に二つの 要素を集約する場合を考える。要荸 $K$ と $L$ を集約す るときの評洒関数 $J_{K L}$ 牥次のように表せる。

$$
J_{K L}=\sum_{i=0}^{n} A_{i}+\sum_{j=1}^{n+2} B_{(j \neq K, L)}^{n+2} B_{j}+C
$$

とて

$$
\begin{aligned}
A_{i}= & (1 / T)\left\{T_{i K} \log \left(T_{i K} / T_{K}\right)\right. \\
& +T_{i L} \log \left(T_{i L} / T_{L}\right)-\left(T_{i K}+T_{i L}\right) \\
& \left.\cdot \log \left[\left(T_{i K}+T_{i L}\right) /\left(T_{K}+T_{L}\right)\right]\right\} \ldots(47) \\
B_{j}= & (1 / T)\left\{T_{K} \log \left(T_{K j} / T_{K}\right)\right. \\
& +T_{L j} \log \left(T_{L j} / T_{L}\right)-\left(T_{K j}+T_{L j}\right) \\
& \left.\cdot \log \left(\left(T_{K j}+T_{L j}\right) /\left(T_{K}+T_{L}\right)\right]\right\} \ldots(48) \\
C= & (1 / T)\left\{T_{K K} \log \left(T_{K K} / T_{K}{ }^{2}\right)\right. \\
& +T_{K L} \log \left(T_{K L} / T_{K} T_{L}\right) \\
& +T_{L K} \log \left(T_{L K} / T_{L} T_{K}\right) \\
& +T_{L L} \log \left(T_{L L} / T_{L}{ }^{2}\right) \\
& -\left(T_{K K}+T_{K L}+T_{L K}+T_{L L}\right) \\
& \cdot \log \left\{\left(T_{K K}+T_{K L}+T_{L K}+T_{L L}\right) /\right. \\
& \left.\left(T_{K}+T_{L}\right)^{2}\right\} \ldots \ldots \ldots \ldots \ldots \ldots \ldots \ldots(49)
\end{aligned}
$$

Ai は, 要素 $i$ 加要素 $K$ 括よび要素 $L へ の フ$ ローを集約化したことにより生ずる挰失を表す。逆 に， $B$ ；要素 $K$ および要素 $L$ から要藮 $j$ へのフ ローの集約化による摃失を表す。また， $C$ は要素 $K$, $L$ 間のフローと，要素 $K$ 之要素 $L$ の各々の自己ルー プの集約化による擅失を表す。

(46)〜 (49)式までと， $A_{i} \geqq 0, B_{j} \geqq 0, C \geqq 0$ で方る とと䘮用いて，次の補助定理力求まる。

補助定理 $1 J_{K L}$ が 0 となるととは， $i=0,1, \ldots$, $n(i \neq K, L) \_j=1, \ldots, n+2(j \neq K, L)$ 飞対して次の 三つの条件が成り立つことと同値である。

$$
\begin{aligned}
T_{i K} / T_{K} & =T_{i L} / T_{L} \\
T_{K j} / T_{K} & =T_{L j} / T_{L} \ldots \ldots \ldots \ldots \ldots \ldots \ldots \ldots \ldots \ldots \ldots \ldots \ldots \ldots \ldots \ldots \ldots \ldots \\
T_{K K} / T_{K}{ }^{2} & =T_{K L} /\left(T_{K} T_{L}\right) \\
& =T_{L K} /\left(T_{L} T_{K}\right)=T_{L L} / T_{L}{ }^{2}
\end{aligned}
$$

電学論 C, 107 巻 8 号, 昭 62 


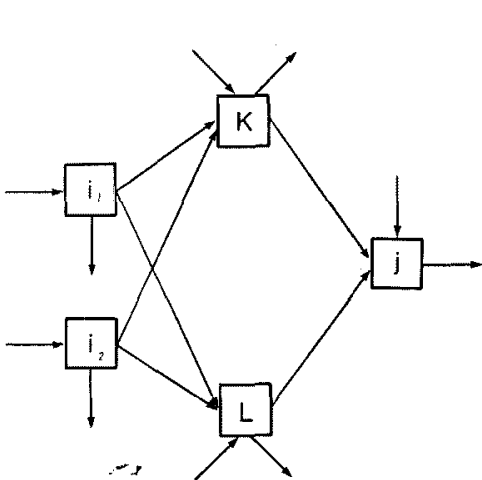

(a)

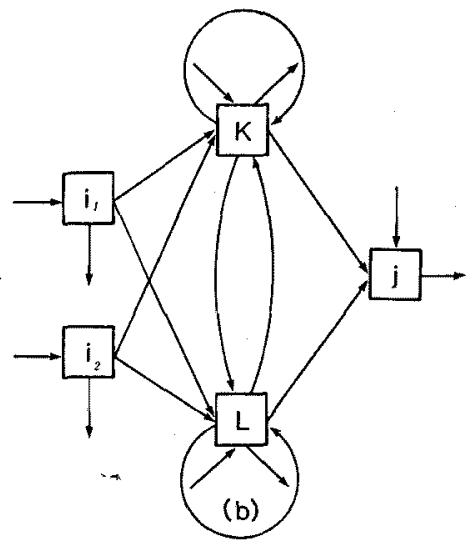

(b)
园 6 並列の位置：性質 4 亿おける嚴密な集約化

Fig. 6. Parallel position in Proposition 4.

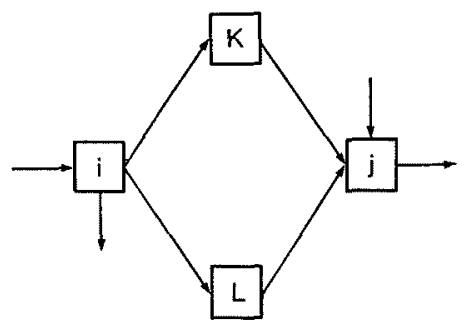

(a)

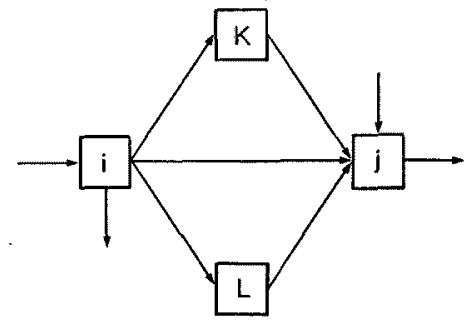

(b)
图 7 完全な並列の位置：性啠 5 におりる厳密な集約化

Fig. 7. Perfect parallel position in Proposition 5.

約化のなかで重要な場合で ある。

性質 5. 因 7 の上う 飞, 要素 $K, L$ が同一の要 素加各々1入力フロー之 同一の要素への各々 1 出力 フローのみをもつときす なわ完全な並列の位置化 あるときに，要素 $K$ と $L$ を集約するととによって損 失は生じない。すなわ方 $J_{K L}=0$ 之なる。

性質 5 は，集約の対象で ある 2 要素が並列の位置に あり, 入力フローと出力フ ローを一つずつだけむつと きは，情報量潗約化侸 り減少しないととを示す。 すなわち、フロー間化他の 条件は必要でない。

性質 4, 5 は, 次の上う 飞 $N$ 個の要素を集約する 場合にまて抁張することが できる。

性筫 6. 次の (a), (b) のように $N$ 個の要素 $K(r)$ $(r=1, \cdots, N)$ 少並列の位置 亿ある場合，てれらの $N$ 個

補助定理 1 と等価な集約化の損失が零の場合，すな わち厳密な集約化の場合の二つのパターンが次の性質 のように求まる。

性質 4. 次の (a)，（b）の上う汇要素 $K と L$ が並 列の関係にある場合は，要素 $K$ 之 $L$ の集約化は敩密 な集約化となる。

(a) 要素 $K, L$ 間にフローがなく $\left(T_{K L}=T_{L K}=\right.$ 0) 加要素 $K, L$ 亿自己ループもない $\left(T_{K K}=T_{L L}\right.$ ＝）とき(図6(a)kその一例を示す)。そのう元， $i=0,1, \ldots, n(i \neq K, L)$ < $j=1, \ldots, n+2(j \neq K, L)$ が，補助定理の条件 (50)，(51) を満足するとき。

(b) 要素 $K ， L$ 間汇可能なすべてのフローが存

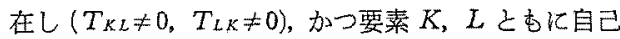
ループを方つ $\left(T_{K K} \neq 0, T_{L L} \neq 0\right)$ とき（図6(b)K その一例を示す $) 。$ そのうえ, $i=0,1, \ldots, n(i \neq K, L)$ 之 $j=1, \ldots, n+2(j \neq K, L)$ が, 補助定理の条件 (50), (51)，(52) 式を满足するとき。

次の性質は，性質 4 の特別な場合であり，䈗密な集
の要素の集約は，笅密な集約化となる。

(a) $N$ 個の要素間にフローがなく $\left(T_{K(r) k(s)=0 \text {, }}\right.$ $(r, s=1, \cdots, N, r \neq s))$, 加すべての要素纪自己ルー

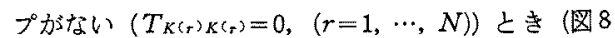
(a) 化その一例者す)。そのう元, $i=0, \cdots, n$ ( $i \neq$ $K(l)(l=1, \cdots, N))$ \& $j=1, \cdots, n+2(j \neq K(l)(l=1$, $\cdots, N)$ ) に対して, 次の条件 (53)式上(54)式加成り立 つとき,

$$
\begin{aligned}
& T_{i K(1)} / T_{K(1)}=\cdots=T_{i K(N)} / T_{K(N)} \\
& T_{K(1) j} / T_{K(1)}=\cdots=T_{K(N) j} / T_{K(N)}
\end{aligned}
$$

(b) すべての要素間に可能なすべてのフローが存 在し $\left.T_{K(r) K(s) \neq 0,}(r, s=1, \cdots, N, r \neq s)\right), \quad$ かつす心 ての要妻加自己ループをあつ $\left(T_{K}(r) K_{(r)}\right) \neq 0,(r=1$, $\cdots, N)$ ) 之き (図 8 (b) Kその一例を示す)。そのう z, $i=0, \cdots, n(i \neq K(l)(l=1, \cdots, N))$ 之 $j=1, \cdots, n$ $+2(j \neq K(l)(l=1, \cdots, N))$ 飞対して，上述の条件 (53) 式と(54)式と次の条件(55)式加成り立つとき。

\section{$T_{K(1) K(1)} /\left(T_{K(1)}\right)^{2}$}




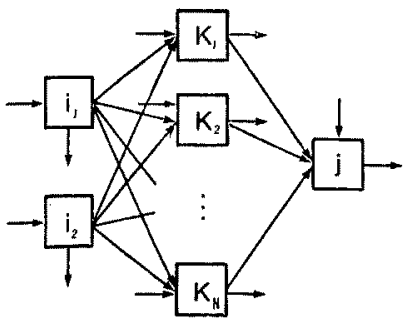

(a)

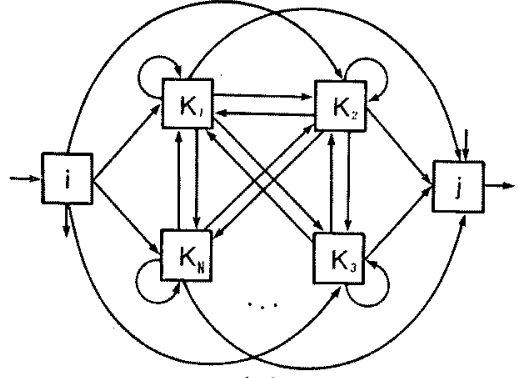

(b)

図 8 並列の位置：性質6における䈗密な集約化

Fig. 8. Parallel position in Proposition 6.

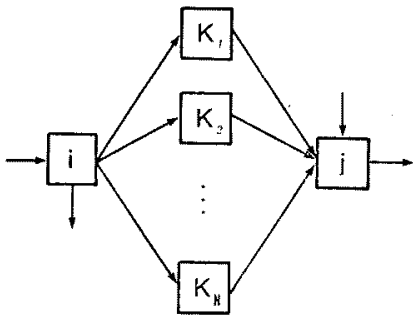

(a)

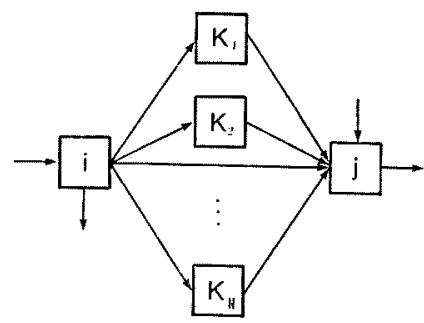

(b)

困 9 完全な並列の位置：性犋 7 における笪密な集約化

Fig. 9. Perfect parallel position in Proposition 7 .

$$
=T_{K(1) K(2)} / T_{K(1)} T_{K(2)}=\cdots
$$$$
=T_{K(m) K(m)} /\left(T_{K(m)}\right)^{2}
$$

性質 7. 図9の上うに, $N$ 個の要素 $K(r)(r=$ $1, \cdots, N)$ 姛一の要素加ら各々1入力フローと同一 の要菜への各々 1 出力フローのみをあつとき，すなわ ち, 完全な並列の位置にあるときに，N個の要素 $K(r)(r=1, \cdots, N)$ を集約することによって損失は生 じない，すなわち $J_{K}(1) \cdots K(N)=0$ となる。

性質 4〜7 は，集約化損失が 0 上なるなめには，並 列の位置にあることが重要であるととを示す。特化， 性質 5 之性質 7 は，厳密な集約化の一つのパターンを 示しており，並列の位置にあ机ばそのほかの条件は必 要でない。

〈5.3〉集約化の損失を伴う場合 一般には䈎約 化は損失を伴う。(45)式の $J$ を最小にする最適な集 約化を求める場合に，要素数が少ない場合仿すへてての 場合を計算して最適なるのを求めることができる。し かしながら，要素の数が多い場合，例えば次汇あげる 例 1 の要素が 17 個の場合ですらすべての場合を計算 することは非常に困嚾である。なにがしかの近似的手 法によるとととなる。紙面の都合で詳しいことは省略
するが，集約化の提失を伴 う場合において屯直列の位 直にあることよりも並列の 位置にあることが損失を少 なくする傾问があることな どがわかる。

すへての場合が計算でき ない場合は，2 個の要素を 一つに集約していく近似的 手法や磪率的最適化法の一 つである Simulated Annealing 法を用いて, 準最 適な集約化を求める。次の 例では集約化後のグループ 数 $m$ を天下り的に与えて 後、そのグループ数になる 中で最適なものを求めてい る。 $n$ 個の要素加らなるネ ットワークに対して，集約 化後のグループ数 $m$ を 1 か らnに順々に変化させてそ の各々に対して最適な集約 を求めると，そのときの損 失は $m$ の增加に対して単調 に隇少するととがわかる。 徉って，損失老最小にする （集約化しない場合が最小よなるため)。しかしなが ら， $m$ を小さくしたいことと損失を小さくしたいこ

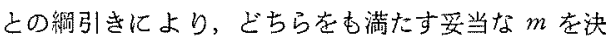
めることは可能である。次化実際の生態亦ットワーク のデータを用いて例を二つ示す。

例 1. Homer 之 Kemp によるフロリダのクリスタ ル川の 17 種類の要素功らる生馝システムの例を 困 10 に示す。この17 個の要素を七つのグループに集 約する。図 10 の点線で示されているように集約結果 加得られる。

集約化で得られた巨視的構造は，生態システムの栄 金構造（階層樹造なぞ）をよく表す。炭索の流れを補 食関係による流机(能動的流れ，奏線）上生体内で使わ れた後のフィードバックの流れ（受勳的流れ，一点鎖 線）に分類する之，図12（a）上図12（b)の上うに二 つの部分グラフに分けることができる。図12（a）は 以下のことを示している。微細植物 (I) と有機堆積物 (III) が漂泳草食動物 (IV) 之底生草食動物 (V)の食料の 源之なる。漂泳草食動物 (IV) 之底生草食動物 $(\mathrm{V})$ は第 一種肉食動物 (VI)の䏣食之なり，第一種肉食動物 (VI) 


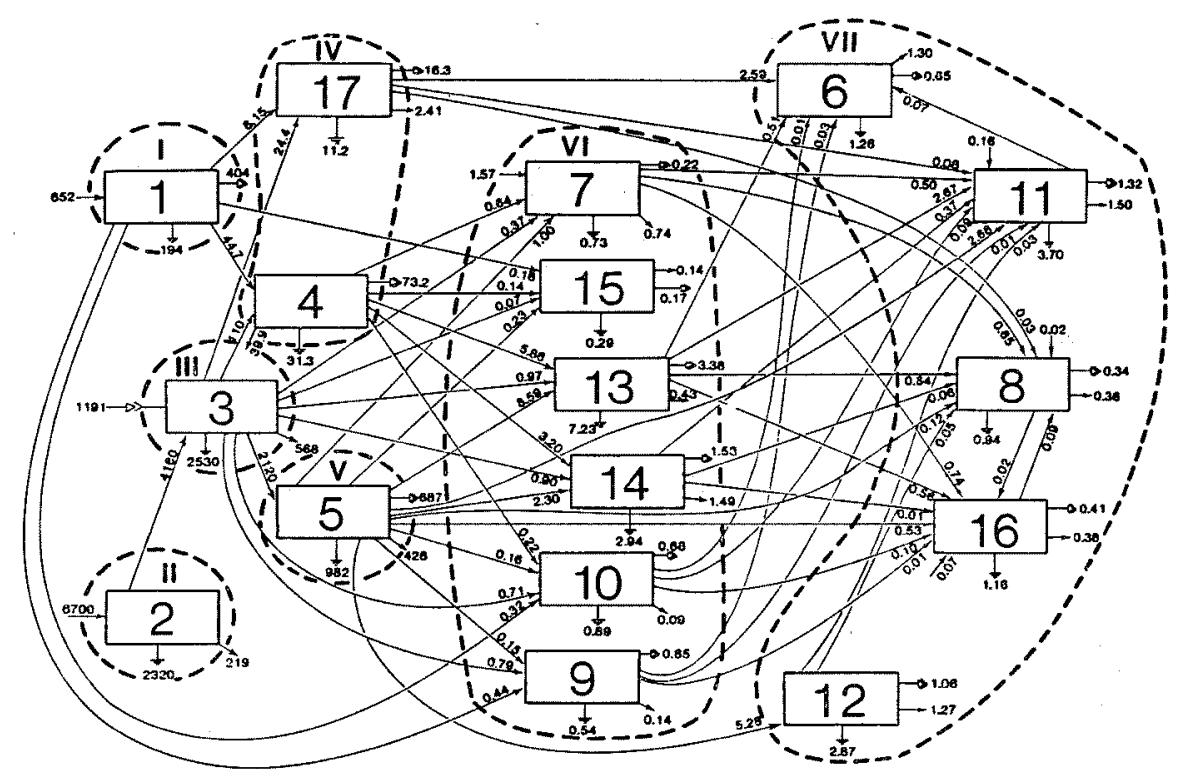

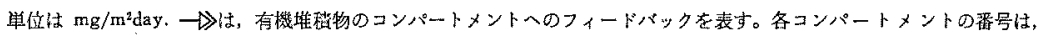

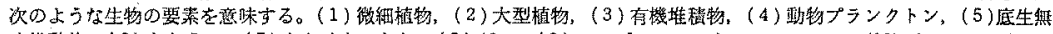

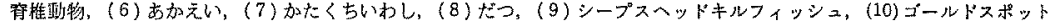

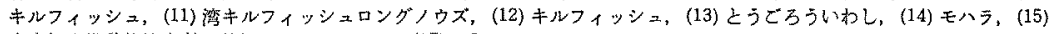

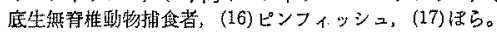

図 10 アメリカ合衆国フロリダクリスタル川の生態ネットワークの炭菜の流れ

Fig. 10. Carbon flows of an ecological network in Crystal River, Florida, U.S.A.

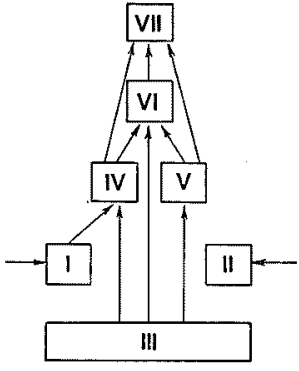

(a)

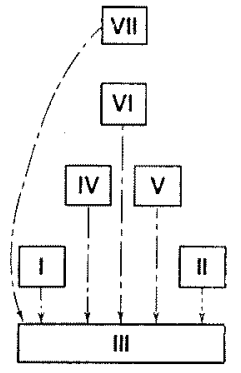

(b)

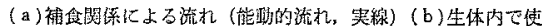

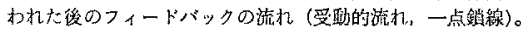

図 11 四 10 の階層棈造

Fig. 11. Hierarchical structure of Fig. 10.

はまた第二種肉食動物・雑食動物 (VII)の飭食となる。

例 2. Steel ${ }^{(6)}$ による北海の 10 霾類の要素から なる生態システムの例を図 12 に示す。この 10 個の 要素を五つのグループに集約する。集約結果は图 12 の点線で示されているようになる。徉って集約化後の 巨視的構造は図 13 のような階層構造になる。

6. おわりに

本文では，生態ネットワークの構造のもつ情報量を

新しく導入することにより，システムの集約化の一手 法を提案するとともに，生態ネットワークのマクロな 構造（主として，階層構造）を見い出すととを行っ た。この新しく導入した生態ネットワークの構造のす つ情報量は，生態システムの自己組織化（遷移）の一 指標となることが期待されている。(昭和 61 年 6 月 2 日受付, 同 62 年 2 月 24 日再受付)

\section{文献}

(1) R.H. Gardner, W. G. Cale, \& R.V. O'Neill: "Robust analysis of aggregation error", Ecology, 63, 1771 (1982).

(2) H. Hirata \& R.E. Ulanowicz: "Large-scale system perspectives on ecological modelling and analysis", Ecological Modelling, 31, 79 (1986).

(3) H. Theil: "Economics and Information Theory", North. Holland (1967).

(4) M. Aoki : "Control of large-scale dynamic systerns by aggregation", IEEE Trans. Autom: Control, 13, 246 (1968).

(5) H. Hirata: "Aggregation method for linear large-scale systems with random coefficients and inputs", Int. J. Systems Science, 9, 515 (1978).

(6) J.H. Steel: "The Structure of Marine Ecosystems", Harvard University Press (1974).

\section{付 録}

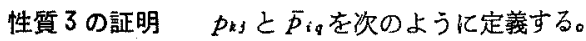
$p_{k j}=P\left(a_{k}, b_{j}\right)=f_{k j} Q_{k}$.

$\bar{p}_{i q}=P\left(\bar{a}_{i}, \bar{b}_{7}\right)=\bar{f}_{i q} \bar{Q}_{i}$ 

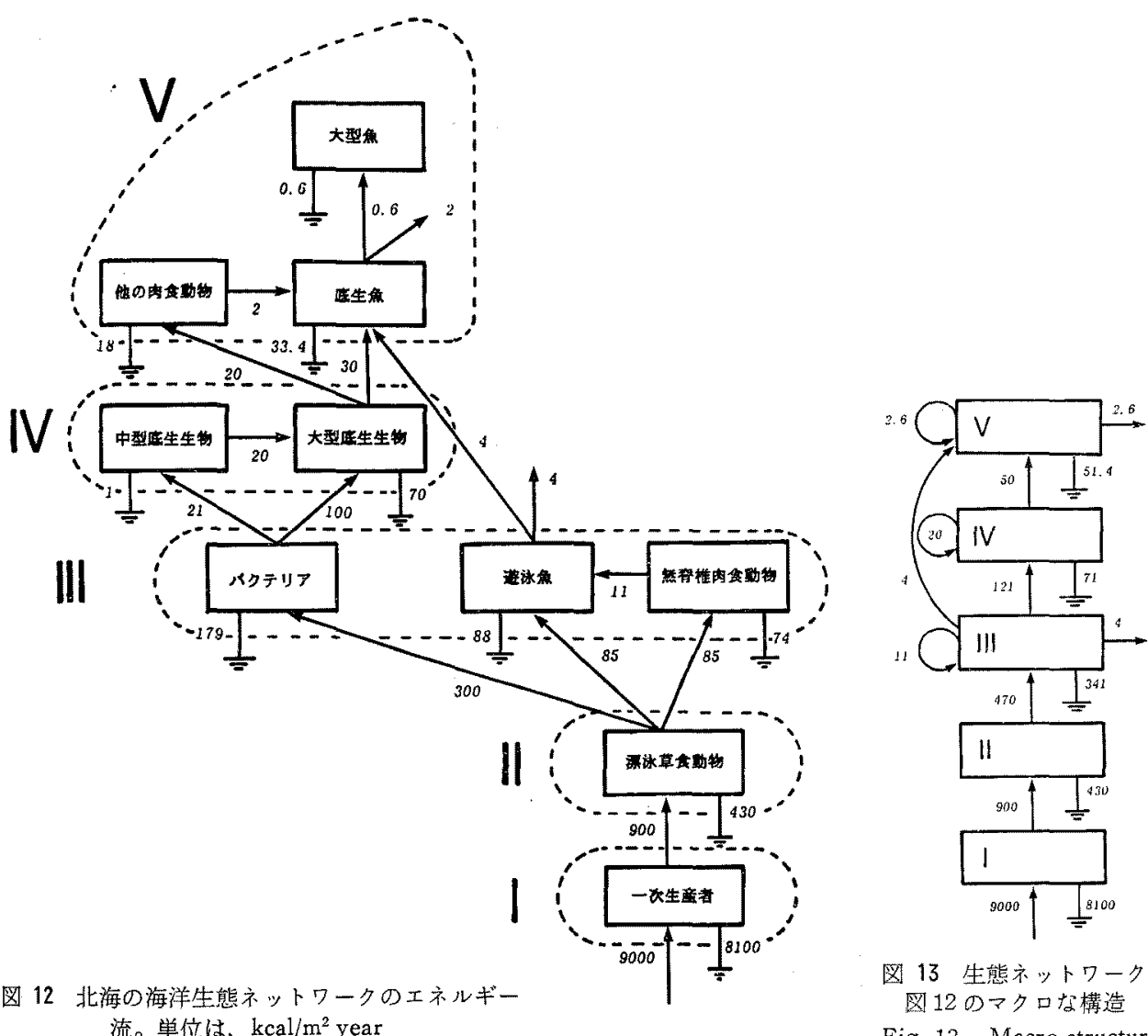

図 13 生態ネットワーク 図12のマクロな箘造

Fig. 13. Macro-structure

Fig. 12. Energy flows in North Sea marine of Fig. 12

ecological network.

ここで

$$
\begin{aligned}
& p_{k}=\sum_{j=0}^{n+2} p_{k j}, \quad p \cdot j=\sum_{k=0}^{n+2} p_{k j} \\
& \bar{p}_{i}=\sum_{q=0}^{n+2} \bar{p}_{i q}, \quad \bar{p}_{\cdot q}=\sum_{i=0}^{n+2} \bar{p}_{i q}
\end{aligned}
$$

と置く之, 次の関係加求まる。

$$
\begin{aligned}
& \bar{p}_{i q}=\sum_{k=0}^{n+2} \sum_{j=0}^{n+2} s_{i k} p_{k j} s_{q j} \\
& \bar{p}_{i}=\sum_{k=0}^{n+2} s_{i k} p_{k}, \ldots \ldots \ldots . . . \\
& \bar{p} \cdot q=\sum_{j=0}^{n+2} p_{\cdot j} s_{q j} \quad \ldots \ldots . . .
\end{aligned}
$$

また

$$
\begin{aligned}
r_{i j} & =\sum_{k=0}^{n+2} s_{i k} p_{k j} \\
c_{k q} & =\sum_{j=0}^{n+2} p_{k j} s_{q j}
\end{aligned}
$$

と膡くことにより，愔報の損失は次のように表せる。

$$
M(N)-M(\bar{N})=\sum_{i=0}^{m+2} \sum_{q=0}^{m+2} p_{i q}\left(M_{a}+M_{b}+M_{c}\right)
$$

ここで

$$
\begin{aligned}
M_{G}= & \sum_{j=0}^{n+2}\left(r_{i j} s_{q j} / \bar{p}_{i q}\right) \log \left\{\left(r_{i j} s_{q j} / \bar{p}_{i q}\right)\right. \\
& \left.\left./\left(p \cdot j s_{q j} / \bar{p} \cdot q\right)\right\} \ldots \ldots \ldots \ldots \ldots \ldots \ldots \text { (付 } 11\right) \\
M_{b}= & \sum_{k=0}^{n+2}\left(s_{i k} c_{k q} / \bar{p}_{i q}\right) \log \left\{\left(s_{i k} c_{k q} / \bar{p}_{i q}\right)\right. \\
& \left.\left./\left(s_{i k} p_{k} / \bar{p}_{i}\right)\right\} \ldots \ldots \ldots \ldots \ldots \ldots \text { (付 } 12\right) \\
M_{c}= & \sum_{k=0}^{n+2} \sum_{j=0}^{n+2}\left(s_{i k} p_{k j} s_{q j} / \bar{p}_{i q}\right) \\
& \log \left\{\left(s_{i k} p_{k j} s_{q j} / \bar{p}_{i q}\right)\right. \\
& \left.\left./\left(r_{i j} s_{q j} / \bar{p}_{i q}\right)\left(s_{i k} c_{k q} / \bar{p}_{i q}\right)\right\} \ldots \ldots \text { (付 } 13\right)
\end{aligned}
$$

$M_{o}, M_{b}, M_{r}$ 各々にシャ/ンの補助定理を用いるし よによりそれれら非負性が示される。従って $M(N) \geqq M(\tilde{N})$

(付14) 